\title{
Chloramphenicol Acetyltransferases Determined by R Plasmids from Gram-negative Bacteria
}

\author{
By DAIRENA F. GAFFNEY AND T. J. FOSTER \\ Microbiology Department, Trinity College, Dublin 2, Ireland \\ AND W. V. SHAW \\ Biochemistry Department, University of Leicester, Leicester LE1 7RH
}

(Received 25 April 1978; revised 24 July 1978)

\begin{abstract}
The mechanism of resistance to chloramphenicol specified by 18 plasmids from Gramnegative bacteria representing different incompatibility groups was investigated. Most determined the drug-inactivating enzyme chloramphenicol acetyltransferase. The enzymes were purified and their properties were compared with those of the previously characterized enzyme types specified by R429 (type I), s-a (type II) and R387 (type III). The type I enzyme was determined by plasmids representing incompatibility groups FII, C, S, I, H, L, O and Com9. Plasmids from incompatibility groups $\mathrm{K}$, I $\gamma$ and the $\mathrm{A}-\mathrm{C}$ complex specified the type III enzyme, while elements representing incompatibility groups $\mathrm{V}$ and $\mathrm{W}$ determined the type II variant.
\end{abstract}

\section{INTRODUCTION}

Chloramphenicol acetyltransferase (CAT) determined by $\mathrm{R}$ plasmids is responsible for the chloramphenicol resistance $\left(\mathrm{Cm}^{\mathrm{r}}\right)$ of most Gram-negative bacteria (Fitton et al., 1978). It catalyses the 3-O-acetylation of chloramphenicol in the presence of acetyl-coenzyme A (Shaw, 1967; Suzuki \& Okamoto, 1967). An inducible $\mathrm{Cm}^{\mathrm{r}}$ determinant which probably confers impermeability to the drug is specified by some $\mathrm{Fi}^{+} \mathbf{R}$ plasmids (Nagai \& Mitsuhashi, 1972). Gram-negative bacterial plasmids are now classified by incompatibility tests (Chabbert et al., 1972; Datta \& Hedges, 1972, 1973, Hedges, 1974, 1975; Hedges \& Datta, 1971; Grindley et al., 1973). Early studies on chloramphenicol resistance suggested that the determinant was mainly associated with $\mathrm{Fi}^{+}$IncFII plasmids. Hedges \& Datta (1971) described some $\mathrm{Fi}^{-} \mathbf{R}$ plasmids that conferred resistance to chloramphenicol; each of these specified the production of CAT. The IncW plasmids and R387 (now classified as IncK; Hedges, 1975) determined novel types of CAT enzymes designated types II and III, respectively (Foster \& Shaw, 1973). These were differentiated biochemically and immunologically from the classical type I CAT determined by IncFII and IncN plasmids.

Plasmids from different incompatibility groups usually have less than $10 \%$ DNA base sequence homology (Grindley et al., 1973). However such plasmids can carry identical antibiotic resistance determinants. This is exemplified by the determinant for TEM $\beta$ lactamase which confers ampicillin resistance in many different bacterical hosts and is specified by several different plasmids (Hedges et al., 1974; Heffron et al., 1975b). The $\beta$-lactamase gene resides in a genetic element which can be translocated to other replicons independently of the host bacterial general (recA-controlled) recombination mechanism (Hedges \& Jacob, 1974; Heffron et al., 1975a; Heffron et al., 1975b). The $\mathrm{Cm}^{\mathrm{r}}$ determinant specifying type I CAT production which was derived from an $\mathrm{Fi}^{+}$IncFII plasmid is also translocatable (Gottesman \& Rosner, 1975; Rosner \& Gottesman, 1977; MacHattie \& Jackowski, 1977). If translocation of a chloramphenicol resistance determinant has occurred 


\begin{tabular}{|c|c|c|c|c|}
\hline Plasmid & $\begin{array}{l}\text { Incom- } \\
\text { patibility } \\
\text { group }\end{array}$ & $\begin{array}{c}\text { CAT } \\
\text { production }\end{array}$ & Resistance determinants* & Source or reference \\
\hline R55 & C & + & $\mathrm{Cm} \mathrm{Ap} \mathrm{Gk} \mathrm{Su}$ & Chabbert et al. (1972) \\
\hline R55-1+ & C & - & $\mathrm{Cm} \mathrm{Su}$ & Chabbert et al. (1972) \\
\hline R 57b & C & + & $\mathrm{Cm} \mathrm{Ap} \mathrm{Gk} \mathrm{Su}$ & Datta \& Hedges (1972) \\
\hline R57b-1 + & C & - & $\mathrm{Cm} \mathrm{Su}$ & Datta \& Hedges (1973) \\
\hline RAl-1b & A & - & $\mathrm{Cm} \mathrm{Su}$ & Datta \& Hedges (1973) \\
\hline R994 & $\mathrm{A}-\mathrm{C}$ & + & $\mathrm{Cm} \mathrm{Sm} \mathrm{Tc}$ & Hedges \& Jacob (1975) \\
\hline R429 & FII & + & Cm Km Tc Ap & Shaw et al. (1972) \\
\hline R16213 & FII & + & $\mathrm{Cm} \mathrm{Sm} \mathrm{Su}$ & N. Datta \\
\hline R726 & $\mathbf{H}$ & + & $\mathrm{Cm} \mathrm{Sm} \mathrm{Su} \mathrm{Tc}$ & Datta \& Olarte (1974) \\
\hline CS Col & I & + & $\mathrm{Cm} \mathrm{Sm} \mathrm{Su}$ & Richmond \& Weidemann (1974) \\
\hline R621ala & $1 \gamma$ & + & $\mathrm{Cm} \mathrm{Ap} \mathrm{Km}$ & Hedges (1974) \\
\hline R387 & $\mathbf{K}$ & + & $\mathrm{Cm} \mathrm{Sm}$ & $\begin{array}{l}\text { Hedges \& Datta (1971); } \\
\text { Hedges (1975) }\end{array}$ \\
\hline R471b & $\mathrm{L}$ & + & Cm Ap Km & Hedges et al. (1975) \\
\hline R478 & $\mathbf{S}$ & + & $\mathrm{Cm} \mathrm{Km} \mathrm{Tc}$ & Hedges et al. (1975) \\
\hline R724 & $\mathbf{O}$ & + & $\mathrm{Cm} \mathrm{Sm} \mathrm{Su} \mathrm{Tc}$ & Datta \& Olarte (1974) \\
\hline R753 & V & + & $\mathrm{Cm}$ Ap Sm Su & Hedges (1975) \\
\hline R901 & V & + & $\mathrm{Cm} \mathrm{Km} \mathrm{Sm} \mathrm{Su}$ & Hedges (1975) \\
\hline s-a & W & + & $\mathrm{Cm} \mathrm{Km} \mathrm{Sm} \mathrm{Su}$ & Hedges \& Datta (1971) \\
\hline R71a & Com9 & + & $\mathrm{Cm} \mathrm{Ap} \mathrm{Sm} \mathrm{Su} \mathrm{Tc}$ & Chabbert et al. (1972) \\
\hline R26 & $\mathbf{P}$ & - & $\mathrm{Cm} \mathrm{Ap} \mathrm{Km} \mathrm{Sm} \mathrm{Su}$ & Stanisich et al. (1976) \\
\hline R527 & $\mathbf{P}$ & - & $\mathrm{Cm} \mathrm{Ap} \mathrm{Km} \mathrm{Sm} \mathrm{Su}$ & Stanisich et al. (1976) \\
\hline
\end{tabular}

* Abbreviations: $\mathrm{Cm}$, chloramphenicol; Ap, ampicillin; Gk, gentamicin/kanamycin; Km, kanamycin; Sn; streptomycin; Su, sulphonamides; Tc, tetracycline.

+ R55-1 and R57b-1 are segregants of R55 and R57b, respectively; thev still confer $\mathrm{Cm}^{\mathrm{r}}$ but no longer produce CAT.

recently in natural populations, then the majority of CAT determinants from different plasmids and bacterial hosts might specify the same types of enzymes.

We have studied the $\mathrm{Cm}^{\mathrm{r}}$ determinants of $R$ plasmids from a variety of incompatibility groups to investigate the distribution of CAT enzyme types and the occurrence of other mechanisms of chloramphenicol resistance in Gram-negative bacteria. The enzymes were purified from the CAT-producing strains and were classified into types I, II and III, as described by Foster \& Shaw (1973), on the basis of electrophoretic mobility, reaction with anti-CAT sera and susceptibility to inhibition by an inhibitor of thiol groups.

\section{METHODS}

Bacterial strains and plasmids. The chloramphenicol resistance-determining plasmids used in this study are listed in Table 1. The bacterial host strain was Escherichia coli $\mathrm{K} 12$ strain 533 Pro- $^{-}$Met- $^{-}$(Clowes \& Hayes, 1968 ) or a spontaneous nalidixic acid resistant derivative of $\mathrm{s} 53$.

Chloramphenicol resistance level determinations. Chloramphenicol was added to Lemco nutrient agar to give concentrations between 20 and $400 \mu \mathrm{g} \mathrm{ml}^{-1}$. Overnight broth cultures grown in the absence or presence of chloramphenicol $\left(1 \mu \mathrm{g} \mathrm{mi}^{-1}\right)$ were diluted $10^{-4}$ in sterile saline and drops (about $0.01 \mathrm{ml}$ ) were applied to the surface of the plates. The resistance level was defined as the concentration of antibiotic which prevented the growth of single colonies after overnight incubation at $37^{\circ} \mathrm{C}$. The composition of the nutrient broth and agar was described previously (Foster \& Walsh, 1974).

Preparation and assay of chloramphenicol acetyltransferase. Bacterial cultures inoculated from single colonies grown on drug-containing plates were grown overnight in $500 \mathrm{ml}$ nutrient broth or in Difco Penassay broth containing $1 \%(\mathrm{v} / \mathrm{v})$ glycerol with shaking ( $\left.200 \mathrm{rev} . \mathrm{min}^{-1}\right)$ in a Gallenkamp orbital incubator at $37^{\circ} \mathrm{C}$. Strains carrying the two IncV plasmids, which were known to be unstable in E. coli hosts (Hedges, 1975), were inoculated into broth which initially contained $20 \mu \mathrm{g}$ chloramphenicol $\mathrm{ml}^{-1}$. The cells were harvested by centrifuging $\left(10000 \mathrm{~g}, 10 \mathrm{~min}, 4^{\circ} \mathrm{C}\right)$, washed in buffer $1(0.05 \mathrm{M}$-Tris $/ \mathrm{HCl} \mathrm{pH} 7.8$ containing $0.1 \mathrm{M}$-2-mercaptoethanol) and finally resuspended in $10 \mathrm{ml}$ buffer 1 . The cells were lysed either in an Aminco French press $\left(420 \mathrm{kgf} \mathrm{cm}^{-2}\right)$ or by sonic disruption with a $100 \mathrm{~W}$ MSE ultrasonic disintegrator at $0^{\circ} \mathrm{C}$ 
$(4 \times 30 \mathrm{~s}$ bursts at maximum output). The cell debris was removed by centrifuging $(30000 \mathrm{~g}, 30 \mathrm{~min})$ and the supernatant fluid was dialysed twice against 50 vol. buffer 1 .

The CAT enzymes were purified by affinity chromatography, as described by Zaidenzaig \& Shaw (1976), using Sepharose-bound 2-amino hexanoyl chloramphenicol. A Pasteur pipette column containing $1 \mathrm{ml}$ of derivatized Sepharose was loaded with about 100 units of enzyme from crude lysates. The enzyme was eluted from the column by a series of salt and buffer washes as previously described, and each fraction was assayed for CAT activity. Those containing enzyme activity were pooled and dialysed twice against buffer 1 . The purified CAT enzymes were concentrated by Amicon A-25 ultrafiltration. Agarose gel electrophoresis showed that most of the enzymes were purified to homogeneity by this method. A faint contaminating band running in front of the CAT enzyme band was detected in some preparations (e.g., R994 CAT).

Chloramphenicol acetyltransferase was assayed by the spectrophotometric method of Shaw \& Brodsky (1968) using a Varian Techtron recording spectrophotometer. Protein concentrations were determined by the method of Lowry et al. (1951).

Inhibition of chloramphenicol acetyltransferases by 5,5'-dithiobis(2-nitrobenzoic acid) (DTNB). The crude lysates and the purified CAT enzymes were tested for sensitivity to DTNB (a reagent which modifies reactive thiol groups) by incubating $10 \mu \mathrm{l}$ of a 5 to 10 units $\mathrm{ml}^{-1}$ preparation of enzyme in reaction mixture with or without $1 \mathrm{mM}-\mathrm{DTNB}$ at $37^{\circ} \mathrm{C} ; 0.1 \mathrm{~mm}$-chloramphenicol was added to portions of the mixture at 2,4 and $6 \mathrm{~min}$ to start the CAT reaction. R901 CAT was also tested for inactivation by the acetyl-CoA component of the reaction mixture after it became apparent that this enzyme was being inactivated in the absence of DTNB.

The percentage reduction in CAT activity after incubation in DTNB for each specified time was calculated. The values were normalized to take into account any reduction in enzyme activity in the control sample (without DTNB) after the same incubation period.

Immunological studies. Crude antisera raised against purified CAT variants were used for all immunological experiments. The type I directed reagent was obtained from a goat immunized with electrophoretically pure type I enzyme specified by plasmid JR66b. This CAT variant has been the subject of protein chemistry studies and amino acid sequence analysis (Zaidenzaig \& Shaw, 1978), and the R429-specified CAT has an identical peptide fingerprint and amino acid composition (W. V. Shaw, unpublished data). The antiserum specific for the type III variants of CAT was raised in a rabbit following immunization with pure CAT specified by plasmid R387. Double diffusion tests were performed in $1 \%$ Difco Noble agar prepared in buffer 1 . The purified CAT preparations $(0.2$ units) were tested for precipitin band formation with the antisera after incubation at $4{ }^{\circ} \mathrm{C}$ for $48 \mathrm{~h}$.

The ability of the antisera to inhibit CAT activity was also tested. The concentrations of the crude lysates were adjusted to the same CAT activity (about 2.4 units $\left.\mathrm{ml}^{-1}\right)$ and to the same protein concentration $(3.7 \mathrm{mg}$ $\mathrm{ml}^{-1}$ ) by adding a combination of buffer 1 and lysate of the $\mathrm{Cm}^{\mathrm{s}} \mathrm{R}^{-}$bacterial strains. A $25 \mu \mathrm{l}$ sample of CAT was incubated with 5 to $25 \mu \mathrm{l}$ of the antiserum, the concentration of which had been adjusted to give a gradation of inhibition with the homologous CAT over this range. Tris/ $\mathrm{HCl}$ buffer $(0.05 \mathrm{M}, \mathrm{pH} 7 \cdot 8)$ w'as added to give a final volume of $50 \mu \mathrm{l}$. After incubation at $4^{\circ} \mathrm{C}$ for $18 \mathrm{~h}$ the samples were assayed for CAT activity,

Electrophoretic mobilities. Purified enzyme preparations were subjected to agarose gel electrophoresis to ascertain the purity of the material and to measure the electrophoretic mobility of the enzyme proteins. About $20 \mu \mathrm{g}$ of the purified proteins were applied to Universal agarose films (Corning ACI, Palo Alto, Calif., U.S.A.) or $1 \%(\mathrm{w} / \mathrm{v})$ agarose slab gels. The electrophoresis was performed at $80 \mathrm{~V}$ for $1.5 \mathrm{~h}$ in $0.05 \mathrm{M}$-sodium barbitol buffer pH $8 \cdot 6$. Protein was stained with naphthalene black $[0 \cdot 123 \%(\mathrm{w} / \mathrm{v})$ in $5 \%(\mathrm{v} / \mathrm{v})$ acetic acid] and destained with $5 \%(\mathrm{v} / \mathrm{v})$ acetic acid washes. CAT activity was located on the gels using the histochemical staining method described by Foster \& Shaw (1973).

\section{RESULTS}

The mechanism of resistance to chloramphenicol specified by $18 \mathrm{Gram}$-negative bacterial $\mathrm{R}$ plasmids (Table 1 ) representing a variety of incompatibility groups was examined. Plasmids R429, s-a and R387 which were previously shown to determine types I, II and III CAT, respectively, (Foster \& Shaw, 1973; Shaw et al., 1972) were included for comparison. The level of resistance to chloramphenicol determined by the plasmids was measured and crude lysates of the strains were tested for the presence of CAT. In order to determine if the CAT enzymes corresponded to the three types described by Foster \& Shaw (1973), the enzymes were purified and the following properties were examined: (i) the electrophoretic mobility of the proteins in agarose gels; (ii) the reaction of the enzyme with antisera prepared against 
Table 2. Comparison of the properties of chloramphenicol acetyltransferases

\begin{tabular}{|c|c|c|c|c|c|c|c|c|}
\hline \multirow[b]{2}{*}{ Plasmid* } & \multirow{2}{*}{$\begin{array}{c}\text { Chloram- } \\
\text { phenicol } \\
\text { resistance } \\
\text { level } \\
\left(/ / \mathrm{g} \mathrm{ml}^{-1}\right)\end{array}$} & \multirow{2}{*}{$\begin{array}{l}\text { Type } \\
\text { of } \\
\text { CAT }\end{array}$} & \multirow{2}{*}{$\begin{array}{l}\text { Electro- } \\
\text { phoretic } \\
\text { mobility } \\
\text { at pH } 8.6 \dagger\end{array}$} & \multicolumn{2}{|c|}{$\begin{array}{c}\text { Precipitation } \\
\text { by antisera }+\end{array}$} & \multicolumn{2}{|c|}{$\begin{array}{c}\text { Inhibition } \\
\text { by antisera } \$\end{array}$} & \multirow{2}{*}{$\begin{array}{c}\text { Rate of } \\
\text { inhibition } \\
\text { by } \\
\text { DTNB|! } \\
\text { (k) }\end{array}$} \\
\hline & & & & Type I & Type III & Type I & Type III & \\
\hline R471b & 250 & I & 0.89 & + & - & 0.070 & 0.009 & 0.046 \\
\hline R478 & 200 & I & 0.92 & + & - & $0 \cdot 124$ & 0.005 & 0.023 \\
\hline (R429) & 350 & I & 1.00 & + & - & $(0.054)$ & 0.000 & 0.021 \\
\hline R16213 & 275 & I & 1.00 & + & - & 0.049 & 0.005 & 0.005 \\
\hline R55 & 300 & I & 1.00 & + & - & 0.059 & 0.000 & 0.013 \\
\hline $\mathrm{R} 57 \mathrm{~b}$ & 300 & I & 1.00 & + & - & 0.076 & 0.005 & 0.000 \\
\hline R726 & 125 & i & 1.03 & + & - & 0.059 & 0.005 & 0.000 \\
\hline $\mathrm{CS} \mathrm{Col}$ & 300 & I & 1.02 & + & - & 0.059 & 0.005 & 0.048 \\
\hline R724 & 250 & 1 & 1.03 & + & - & 0.065 & 0.000 & 0.002 \\
\hline R71a & 325 & I & 1.03 & + & - & 0.070 & 0.009 & 0.000 \\
\hline R901 & 75 & II & 1.44 & - & -. & 0.022 & 0.000 & $0 \cdot 133$ \\
\hline$(s-a)$ & 150 & II & 1.46 & - & - & 0.022 & 0.009 & 0.074 \\
\hline R753 & 125 & II & 1.57 & - & - & 0.000 & 0.000 & 0.353 \\
\hline (R387) & 200 & III & $1 \cdot 20$ & - & + & 0.043 & $(0 \cdot 046)$ & 0.035 \\
\hline R994 & 150 & III & $1 \cdot 20$ & - & + & 0.038 & 0.041 & 0.039 \\
\hline R621ala & 150 & III & $1 \cdot 20$ & - & + & 0.043 & 0.041 & 0.027 \\
\hline \multicolumn{9}{|c|}{$\mathrm{R}^{-}$host strains } \\
\hline $\mathrm{J} 53$ & 4 & None & & & & & & \\
\hline $\mathrm{J} 53 \mathrm{Nal}^{\mathrm{r}}$ & 4 & None & & & & & & \\
\hline
\end{tabular}

* Plasmids R471b, R478, R429, R57b, R753, R387 and R621ala were harboured by the E. coli strain $\mathrm{J53}$; the other plasmids were carried by a Nalr mutant of $\mathrm{J} 53$. The plasmid numbers in parentheses denote the producers of the standard type I, type II and type III chloramphenicol acetyltransferases.

+ Electrophoretic mobilities are expressed relative to that of the R429-determined enzyme

$\ddagger+$, An unequivocal immunoprecipitate which gave a line of identity with the precipitate of the standard enzyme and antiserum. -, No immunoprecipitate.

$\S$ Each enzyme was titrated with both of the antisera as described in Methods. The activity remaining after $18 \mathrm{~h}$ incubation at $4{ }^{\circ} \mathrm{C}$ was determined and the stoicheiometry of the neutralization reaction was determined from the slope of the titration curve. The values obtained for the prototype enzymes against their respective antisera are shown in parentheses. The dimensions for the neutralization are units CAT activity neutralized per $\mu 1$ antiserum.

I! The rate of inactivation of each enzyme in the presence of DTNB was calculated graphically from the equation $\ln E / E_{0}=-k t$, where $E / E_{0}$ is the fraction of the initial enzyme activity remaining after treatment with the inhibitor for time $t$ (Zaidenzaig \& Shaw, 1978).

type I and type III CAT; (iii) the loss of enzyme activity following incubation with $5,5^{\prime}-$ dithiobis(2-nitrobenzoic acid).

\section{Chloramphenicol resistance levels and the production of chloramphenicol acetyltransferase}

The level of resistance to chloramphenicol specified by the plasmids in the E. coli K12 host strain 553 and the CAT activity in crude lysates were measured (Tables 2 and 3). With the exception of R726, the strains that were subsequently shown to produce type I CAT exhibited the highest chloramphenicol resistance levels $\left(200\right.$ to $\left.350 \mu \mathrm{g} \mathrm{ml}^{-1}\right)$. The three strains that produced type III CAT had intermediate levels of resistance (150 to $\left.200 \mu \mathrm{g} \mathrm{ml}^{-1}\right)$, and those that formed type II CAT had the lowest resistance levels (75 to $150 \mu \mathrm{g} \mathrm{ml}^{-1}$ ).

Five $\mathrm{Cm}^{\mathrm{r}}$ strains were devoid of CAT activity, i.e. less than 0.0005 units activity per $\mathrm{mg}$ cell protein. (About 1.5 units of type I CAT per $\mathrm{mg}$ protein would be required to give a chloramphenicol resistance level of $100 \mu \mathrm{g} \mathrm{ml}^{-1}$.) Furthermore, these strains exhibited a higher resistance level when grown in the presence of $1 \mu \mathrm{g}$ chloramphenicol $\mathrm{ml}^{-1}$, which suggests that the $\mathrm{Cm}^{\mathrm{r}}$ determinant was inducible (Table 3 ). This has subsequently been confirmed by broth growth-and-challenge tests (D. F. Gaffney \& T. J. Foster, unpublished experiments). Two of the plasmids, R55-1 and R57b-1, are segregants of plasmids R55 and R57b which determine type I CAT. These plasmids must therefore carry two determinants of chloramphenicol resistance. 
Table 3. Chloramphenicol resistance levels conferred by plasmids which do not specify chloramphenicol acetyltransferase

\begin{tabular}{lcc} 
& \multicolumn{2}{c}{$\begin{array}{c}\text { Chloramphenicol resistance level } \\
\left(\mu \mathrm{g} \mathrm{ml}^{-1}\right)\end{array}$} \\
Plasmid* & Uninduced & Induced \\
R- & 4 & 4 \\
R26 & 15 & 50 \\
R527 & 15 & 50 \\
R55-1 & 100 & 150 \\
R57b-1 & 100 & 150 \\
RA1-1b & 25 & 100
\end{tabular}

* Plasmids were harboured by the Nal ${ }^{\mathrm{r}}$ mutant derivative of the E. coli strain $\mathrm{J} 53$.

+ Cultures were induced by growth in broth containing $1 \mu \mathrm{g}$ chloramphenicol $\mathrm{ml}^{-1}$.

\section{Electrophoretic mobilities}

The prototype CAT variants identified by Foster \& Shaw (1973) had characteristic electrophoretic mobilities in polyacrylamide gels. The purified CAT proteins were therefore compared by agarose gel electrophoresis (Table 2). The putative type I CAT proteins had the lowest anodic electrophoretic mobilities, in accordance with previous findings (Foster \& Shaw, 1973). However, very slight but reproducible differences in migration necessitated subdivision of the group. Thus R471b and R478 determined the slowest moving enzymes, having electrophoretic mobilities relative to the R429 enzyme of 0.89 and 0.92 , respectively. The CAT proteins specified by R16213, R57b and R55 migrated at the same rate as the prototype type I enzyme specified by R429. The fastest type I CAT migration was shown by the enzymes directed by R726, R724, R71a and CS Col, with mobilities relative to R429 CAT of 1.02 to 1.03 .

The putative type II CAT variants determined by R753, s-a and R901 showed the fastest anodic electrophoretic mobilities, although small differences in relative mobilities were noted. Thus the rate of migration towards the anode for R753 CAT was greater than that for s-a CAT, which in turn migrated marginally faster than R901 CAT. Their mobilities relative to that of the R429 enzyme were $1.57,1.46$ and 1.44 , respectively.

The type III CAT variants determined by R621ala, R994 and R387 had identical mobilities between the type I and type II CAT values. Their mobilities relative to R429 CAT were $1 \cdot 20$.

The observed electrophoretic mobilities of the type II and type III CAT enzymes differed from those reported by Foster \& Shaw (1973) who showed that R387 (type III) CAT migrated faster than the type II CAT variants specified by s-a, RA3 and RA4. Thus the electrophoretic mobility of type II CAT was originally reported to lie between that of the type I and type III enzymes. This discrepancy can only be attributed to the different electrophoretic techniques employed in the two studies. To confirm this, crude lysates of strains producing the previously identified RA3 and RA4 type II CAT were subjected to agarose gel electrophoresis. These CAT bands, identified in situ with a histochemical stain, were found to migrate at the same fast rate as s-a CAT.

\section{Reactions with anti-chloramphenicol acetyltransferase sera}

The ability of antisera against a type I CAT and a type III CAT to form precipitin bands in Ouchterlony gels and to inhibit the catalytic activity of the enzymes was determined. The results are summarized in Table 2.

The putative type I CAT enzymes were rapidly inactivated by the anti-I serum but were unaffected in tests with the anti-III serum. They formed precipitin bands which gave reactions of identity with the immunoprecipitate formed by the serum and the prototype 
CAT specified by $R 429$. No reaction occurred between any of the type I CAT enzymes and the anti-III serum.

The catalytic activity of the R387, R994 and R621ala CAT variants was rapidly lost after incubation with the anti-III serum. These enzymes were also inhibited by the anti-I serum, but less markedly than the type I CATs. This effect is characteristic of the standard type III R387 CAT and suggests that some surface antigenic determinants may be shared by the type I and type III enzymes. In addition, the R994 and R621ala CAT proteins formed immunoprecipitates with the anti-III serum but none were formed in tests with the anti-I serum. R994 formed two precipitin bands with the anti-III serum, one of which gave a cross-reaction of partial identity with the single R387 and R621ala immunoprecipitates. The second band may represent a contaminating protein which was common to the R387 preparation used to raise the serum and the R994 CAT prepared in this study. It is noteworthy that the R994 CAT preparation exhibited two protein bands on agarose gel electrophoresis; the faster moving band was devoid of catalytic activity as shown by the histochemical staining method.

The catalytic activity of the putative type II CAT variants was not affected by the anti-III CAT serum. However, each of the three enzymes behaved differently in tests with the anti-I serum. Thus, R753 CAT activity was unaffected by the anti-I serum whereas the R901 and s-a enzymes were slightly inactivated. None of the type II CAT preparations reacted significantly with either the anti-I or the anti-III CAT serum in double diffusion tests.

\section{Inhibition by 5,5'-dithiobis(2-nitrobenzoic acid)}

The CAT enzymes which were classified as type II by Foster \& Shaw (1973) were unusual in that their catalytic activity was rapidly lost during pre-incubation with DTNB, a thiol reagent used in the CAT enzyme assay. The DTNB sensitivity of the 13 new CAT variants and the standard type I, II and III enzymes was therefore examined. Some of the type I CAT enzymes and each of the type III variants were slightly inhibited by DTNB (Table 2). The type II enzymes (specified by plasmids R753, R901 and s-a) were rapidly inactivated. Preliminary experiments with R901 CAT indicated that this enzyme was being inactivated in the control sample containing reaction mixture without DTNB. It was demonstrated that R901 CAT was inactivated by pre-incubation with either the acetyl-CoA or the DTNB component of the reaction mixture but was not affected by incubation at $37^{\circ} \mathrm{C}$ in buffer alone. The acetyl-CoA effect has also been observed in another context. Zaidenzaig \& Shaw (1978) have shown that at least one type I variant undergoes a very slow inactivation in the presence of acetyl-CoA, although the rate constant for this process is very much lower than that observed for the R901 enzyme. The augmentation of the acetyl-CoA effect observed in the latter case may ultimately prove to be of importance in studies of the mechanism of enzymic chloramphenicol acetylation.

\section{DISCUSSION}

The results presented in this paper demonstrate that the most common mechanism of chloramphenicol resistance determined by plasmids from different incompatibility groups is the inactivation of the drug by CAT. Two IncP plasmids and segregants derived from the CAT-producing IncC plasmids R55 and R57b exhibited a lower level of chloramphenicol resistance which was inducible and did not involve CAT. Plasmids R57b and R55 must therefore carry two $\mathrm{Cm}^{\mathrm{r}}$ determinants since they also specify the production of type I CAT. It is possible that the mechanism of chloramphenicol resistance in these strains without detectable CAT is a barrier to the uptake of the drug as described for some other non-CATproducing $\mathrm{Cm}^{\mathrm{r}}$ strains by Nagai \& Mitsuhashi (1972). This is currently being investigated.

The CAT variants specified by R471b, R478, R55, R57b, R16213, R724, R71a, CS Col and R726 were assigned to type I. Each enzyme was inactivated by anti-type I CAT serum with the formation of an immunoprecipitate which gave a reaction of identity with that 
obtained in the standard type I CAT antigen-antibody system. Furthermore, each enzyme had a slow electrophoretic mobility and most were insensitive to DTNB. The electrophoretic mobilities of some of the enzymes differed slightly from the prototype R429 CAT. In addition, some of the purified type I enzymes were slightly inactivated by pre-incubation with DTNB. This suggests that type I CAT variants from different sources are not absolutely identical. The heterogeneity could be due to single amino acid changes which do not alter either catalytic activity or the majority of the surface antigenic determinants. The specific details of the interaction of DTNB with the type I variants of CAT have been studied by Zaidenzaig \& Shaw (1978). The four half-cysteine residues present in the CAT monomer vary in their reactivity towards DTNB and other anti-thiol reagents.

The putative type III CAT variants specified by R994 and R621ala were closely related to R387 CAT. They were rapidly inactivated by antiserum to R387 CAT and also gave reactions of identity in agar double diffusion tests with the R387 CAT and its antiserum. Each CAT was also partially inactivated by anti-type I CAT serum but failed to form visible immunoprecipitates in Ouchterlony double diffusion tests. This could indicate that the type III CAT enzymes share some surface antigenic determinants with the type I enzyme. An evolutionary relationship between the type I and type III CAT variants is also suggested by the fact that the subunits of the two types of enzymes can form hybrids in vivo and in vitro (Shaw et al., 1972).

The R753 and R901 CAT enzymes were assigned to CAT class II primarily on the basis of their sensitivity to DTNB, a characteristic of the s-a, RA3 and RA4 specified enzymes described by Foster \& Shaw (1973). However, this CAT group is probably heterogeneous, as each of the putative type II enzymes differed in a number of other properties. The enzymes determined by R901 and s-a were partially inactivated by anti-type I CAT serum, whereas the R753-specified CAT was unaffected. The R901 enzyme differed from the other two in that it was inactivated by pre-incubation with acetyl-CoA as well as DTNB. The variation in electrophoretic mobility of the enzymes also indicates heterogeneity within the type II group.

Type I CAT is specified by plasmids from incompatibility groups FII, C, S, I, H, L, O and Com 9 suggesting that the same ancestral $\mathrm{Cm}^{\mathrm{r}}$ determinant may have been disseminated to different bacterial hosts by a transposition mechanism similar to that proposed for the TEM $\beta$-lactamase gene (Hedges et al., 1974). Indeed a type I CAT determinant, termed Tn9, is known to be transposable (Gottesman \& Rosner, 1975). However, Tn9 does not exist as such on $\mathbf{R}$ plasmids but was constructed from a F-like $\mathbf{R}$ plasmid by $\mathrm{P} 1$ transduction. Iida \& Arber (1977) have suggested that the entire resistance-determinant region of $\mathrm{R} 100$ was transposed on to the P1 phage genome to yield a P1CmSmSu recombinant. This was too large to be accommodated in the phage head and the selection of plaque-forming derivatives which retained chloramphenicol resistance resulted from deletion of the $\mathrm{Sm}^{\mathrm{r}}$ and $\mathrm{Su}^{\mathrm{r}}$ genes to yield the $\mathrm{P} 1 \mathrm{Cm}$ phage. This may explain the failure of attempts to demonstrate the transposability of the $\mathrm{Cm}^{\mathrm{r}}$ determinants carried by the type I CAT-determining plasmids by the method of Shapiro \& Sporn (1977) (T. J. Foster, unpublished data).

We wish to thank Drs N. Datta, D. Bouanchaud and P. Bennett for supplying the strains. W.V.S. received project grant support from the Medical Research Council of the United Kingdom. D. G. was the recipient of an E.M.B.O. short-term fellowship.

\section{REFERENCES}

Chabbert, Y. A., Scavizzi, M. R., WitchitZ, J. F., Gerbaud, G. R. \& Bouanchaud, D. H. (1972). Incompatibility groups and the classification of $f^{-}$resistance factors. Journal of Bacteriology 112, 666-675.

Clowes, R. C. \& HAyes, W. (1968). Experiments in
Microbial Genetics. Oxford: Blackwell Scientific Publications.

Datta, N. \& Hedges, R. W. (1972). R factors identified in Paris, some conferring gentamicin resistance, constitute a new compatibility group. Annales de l'Institut Pasteur 123, 849-852. 
DATTA, N. \& HEDGES, R. W. (1973). R factors of compatibility group A. Journal of General Microbiology 74, 335-336.

DatTa, N. \& OlarTe, J. (1974). R factors in strains of Salmonella typhi and Shigella dysenteriae 1 isolated during epidemics in Mexico: classification by compatibility. Antimicrobial Agents and Chemotherapy 5, 310-317.

Fitton, J. E., Packman, L. C., Harford, S. Zaidenzaig, Y. \& Shaw, W. V. (1978). Plasmids and the evolution of chloramphenicol resistance. In Microbiology-1978, pp. 249-252. Edited by D. Schlessinger. Washington: American Society for Microbiology.

Foster, T. J. \& Shaw, W. V. (1973). Chloramphenicol acetyltransferases specified by $f^{-} \mathbf{R}$ factors. Antimicrobial Agents and Chemotherapy 3, 99-104.

Foster, T. J. \& Walsh, A. (1974). Phenotypic characterization of $\mathbf{R}$-factor tetracycline resistance determinants. Genetical Rescarch 24, 333-343.

GotTesman, M. M. \& Rosner, J. F. (1975). Acquisition of a determinant for chloramphenicol resistance by coliphage lambda. Proceedings of the National Academy of Sciences of the United States of America 72, 5041-5045.

Grindley, N. D. F., Humphries, G. O. \& AnderSON, E.S. (1973). Molecular studies of $\mathbf{R}$ factor compatibility groups. Journal of Bacteriology 115, 387-398.

Hedges, R. W. (1974). R factors from Providence. Journal of General Microbiology 81, 171-181.

Hedges, R. W. (1975). R factors from Proteus mirabilis and $P$. vulgaris. Journal of General Microbiology 87, 301-311.

HedGes, R. W. \& DATta, N. (1971). $f i^{-}$R factors giving chloramphenicol resistance. Nature, London 234, 220-221.

HeDGES, R. W. \& JACOB, A. E. (1974). Transposition of ampicillin resistance from RP4 to other replicens. Molecular and Generul Genetics 132, $31-40$.

HedGes, R. W. \& JACOB, A. E. (1975). A 98 megadalton $\mathbf{R}$ factor of compatibility group $\mathbf{C}$ in a Vibrio cholerae El Tor isolate from Southern U.S.S.R. Journal of General Microbiology 89, 383386.

Hedges, R. W., Datta, N., Kontomichalou, P. \& Smrrh, J. T. (1974). Molecular specificities of $\mathbf{R}$ factor-determined beta-lactamases: correlation with plasmid compatibility. Journal of Bacterio$\log y 117,56-62$.

Hedges, R. W., Rodriguez-Lemoine, V. \& DatTa, N. (1975). R factors from Serratia marcescens. Journal of General Microbiology 86, 88-92.

Hefroon, F., Rubens, C. \& Falkow, S. (1975a). Translocation of a plasmid DNA sequence which mediates ampicillin resistance: molecular nature and specificity of insertion. Proceedings of the National Academy of Sciences of the United States of .America 72, 3623-3627.

Heffron, F., Sublett, R., Hedges, R. W., Jacob, A. \& Falkow, S. $(1975 b)$. Origin of the TEM beta-lactamase gene found on plasmids. 'ournal of Bacteriology 122, 250-256.

IIDA, S. \& ARBER, W. (1977). Plaque forming specialized transducing phage $\mathrm{Pl}$ : isolation of
P1CmSmSu, a precursor of P1Cm. Molecular and General Genetics 153, 259-269.

Lowry, O. H., Rosebrough, N. J. Farr, A. L. \& RaNdall, R. J. (1951). Protein measurement with the Folin phenol reagent. Journal of Biological Chemistry 193, 265-275.

MacHattie, L. F. \& JaCKowsKi, J. B. (1977). Physical structure and deletion effects of the chloramphenicol resistance element $\operatorname{Tn} 9$ in phage lambda. In DNA Insertion Elements, Plasmids and Episomes, pp. 219-228. Edited by A.I. Bukhari, J. A. Shapiro \& S. Adhya. Cold Spring Harbor, New York: Cold Spring Harbor Laboratory.

Nagai, Y. \& Mitsuhashi, A. (1972). New types of $R$ factors incapable of inactivating chloramphenicol. Journal of Bacteriology 109, 1-7.

RichmoND, M. H. \& WEIDEMANN, B. (1974). Plasmids and bacterial evolution. Symposia of the Society for General Microbiology 24, 59-85.

Rosner, J. L. \& Gotresman, M. M. (1977). Transposition and deletion of $\mathrm{Tn} 9$, a transposable element carrying a gene for chloramphenicol resistance. In DNA Insertion Elements, Plasmids and Episomes, pp. 213-218. Edited by A.I. Bukhari, J. A. Shapiro \& S. Adhya. Cold Spring Harbor, New York: Cold Spring Harbor Laboratory.

Shapiro, J. A. \& Sporn, P. (1977). Tn402: a new transposable element determining trimethoprim resistance that inserts in bacteriophage lambda. Journal of Bacteriology 129, 1632-1635.

SHAw. W. V. (1967). The enzymic acetylation of chloramphenicol by extracts of R-factor-resistant Escherichia coli. Journal of Biological Chemistry 242, 687-693.

Shaw, W. V. \& Brodsky, R. F. (1968). Characterization of chloramphenicol acetyltransferase from chloramphenicol resistant Staphylococcus aureus. Journal of Bacteriology 95, 28-36.

Shaw, W. V., Sands, L. C. \& DatTa, N. (1972). Hybridization of variants of chloramphenicol acetyltransferases specified by $f^{+}$and $f^{-} \mathbf{R}$ factors. Proceedings of the National Academy of Sciences of the United States of America 69, 3049 3053.

Stanisich, V. A., Bennett, P. M. \& Ortiz, J. M. (1976). A molecular analysis of transductional marker rescue involving $\mathbf{P}$-group plasmids in Pseudomonas aeruginosa. Molecular and General Genetics 143, 333-337.

Suzukı, Y. \& Oкамото, S. (1967). The enzymic acetylation of chloramphenicol by the multiple drug-resistant Escherichia coli carrying $\mathbf{R}$ factor Journal of Biological Chemistry 242, 4722-4730.

Zaidenzaig, Y. \& Shaw, W. V. (1976). Affinity and hydrophobic chromatography of three variants of chloramphenicol acetyltransferase specified by $\mathrm{R}$ factors in Escherichia coli. FEBS Letters 62, 266-271.

Zaidenzaig, Y. \& Shaw, W. V. (1978). The reactivity of sulphydryl groups at the active site of an $\mathbf{R}$ factor-specified variant of chloramphenicol acetyltransferase. European Journal of Biochemistry 83, 553-562. 